Applications of Electricity. - It has been sometimes thought that a copper cable of enormous thickness would be required to transmit the hydraulic power of Niagara falls to New York. Prof. Ayrtom has shown that the whole power could be transmitted by a slender copper wire, provided that the wire could be thoroughly insulated. He has also shown that the only hindrance to receiving the whole power is the mechanical friction of the machines. It is therefore believed that immense machines, with continuous currents, with detached exciters or magneto-electric machines, driven iery rapidly by steam engines, will hold an important place in the future transmission of energy. With such machines it would be possible to warm, to light and to give workshops the power which is necessary to move all their machinery by means of an ordinary telegraph wire, thoroughly insulated and transmitting energy from great distanees. Prof. Perry thinks that it will sometime become prssible to see what is going on in remote places by means of electricity. - Ita Lumiere Electrique.

C.

\title{
Decomposition of Nitrates by Decomposition in the Dark.
}

-In plants which grow in the dark, although there is a regular organization and development of stalks, roots and appendages, there is a persistent elimination of a portion of the material which was contained in the seed. 'The tissue of the organs which are developed under a shelter from light is firm and strongly impregnated with a liquid which has a sensibly acid reaction. The cotyledons are, therefore, provided with the principles which are necessary for the life of the embryo; but nocturnal vegetation is mable to fix the carbon of the arbonic acid which is in the air. Botssingault has experimented in order to find whether this impotence extends to the fertilizing substances, which the roots commonly draw from the soil; if, for example, nitrogenous compounds, such as the nitrates and the ammoniacal salts, are assimilated. He immediately found that if a measured quantity of these salts is added to a sterile soil a considerable portion clisajpears entirely, and only a part of the quantity is found in the growth. IIe therefore concludes that a soil which harl been rendered entirely sterile contains traces of organic substances after vegetation in the dark. These substances are probahly due to an exeretion from the root, which exereises a destructive aretion upon the arde of the nitrates that were added to the soil.-Amn. he chim. of de lhys. 